\title{
28. CHEMISTRY OF ALTERATION MINERALS FROM DEEP SEA DRILLING PROJECT SITES 501, 504, AND 5051
}

\author{
A. C. Adamson, Department of Geology, The University, Newcastle upon Tyne, NE1 7RU, England
}

\begin{abstract}
Over 300 electron microprobe and wet chemical analyses were made of alteration minerals (mostly clays) in basalts from DSDP Sites 501, 504, and 505 in the Costa Rica Rift. These analyses are displayed using a three-dimensional graphical method. Several alteration minerals have been identified, of which saponites are by far the most common. In situ alteration of basalt glass has produced montmorillonite-like minerals rich in the less-mobile elements such as $\mathrm{Al}$ and Ti. Talc-like minerals commonly replace olivine and act as fillings to vesicles. Three other alteration minerals have been recognized chemically, rich in $\mathrm{Na}$ and $\mathrm{Ca}$, but these are presently unidentified. There is no evidence for systematic change of mineral chemistry with depth.
\end{abstract}

\section{INTRODUCTION}

The alteration of ocean-floor basalts by sea water has been studied in considerable detail in rocks from many different environments since the beginning of the Deep Sea Drilling Project (Andrews, 1977; Baragar, et al., 1977; Bass, 1976; Bohlke, et al., 1980; Donnelly, 1978; Hart, 1973; Peterson, 1978; Pritchard, 1979; Pritchard et al., 1978; Scarfe and Smith, 1977; Scott and Hajash, 1976). None of these, however, have specifically attempted to distinguish between or investigate differences in the alteration chemistry of sites with contrasting geothermal environments. DSDP Legs 68,69 , and 70 made the first positive attempt to remedy this situation, by studying in detail a section of the ocean floor on the southern flank of the Costa Rica Rift, where both "open" and "closed" hydrothermal circulation was thought to be operating. For the first time, these legs have allowed the opportunity to study basalt alteration in rocks of similar petrographic type, but from two opposite geothermal environments.

This study is essentially a geochemical one; the petrographic relationships between the various alteration phases are described elsewhere (Honnorez et al.; Noack et al.; Kurnosov et al.; Pertsev and Boronikhin, all this volume). Changes in alteration chemistry are identified on a local and extended scale, with the aim of recognizing relationships which correspond to an increase in depth or a change in the local petrographic environment. The fine layering apparent in many precipitated clays has been analyzed in detail, and the geochemical variations have been used as an indicator of local fluctuations in fluid chemistry with time.

Samples were selected from areas of the core where veins, oxidation rims, pseudomorphs, breccias, and cavity and vesicle fillings were particularly abundant, indi-

\footnotetext{
${ }^{1}$ Cann, J. R., Langseth, M. J., Honnorez, J., Von Herzen, R. D., White, S. M., et al., Init. Repts. DSDP, 69: Washington (U.S. Govt. Printing Office).
}

cating intense alteration. The resulting bias of this sampling should be remembered when reading this report.

Over 300 electron microprobe analyses were collected of various alteration phases from 23 thin-sections evenly distributed in cores from Holes 504A, 504B, 505, and 505B. A further 25 analyses were made using wet chemical methods on separates from samples rich in clay. Ferrous iron content was determined by normal colorimetric means. Electron-microprobe analysis was conducted on microprobe equipment with energy-dispersive spectrometry (Department of Earth Sciences, Cambridge University, England), producing 14 element analyses. Xray diffractograms and powder photographs made with a 114.6-mm Debye-Scherrer camera and $\mathrm{CoK} \alpha$ radiation with $\mathrm{Fe}$ filter have aided in the identification and grouping of the various alteration minerals.

A three-dimensional graphical method has been developed to enable rapid categorization of large numbers of unknown-clay analyses. Alteration products are considered to be 2:1 layered clays, and analyses are recalculated on the basis of 22 oxygens with the inter-layer charge and total $\mathrm{Al}+\mathrm{Fe}^{3+}$ determined. Depicted graphically, similar analyses form clusters. The introduction of a third axis, measuring the dioctahedral, trioctahedral, or intermediate character of analyses, subdivides clusters into linear trends along which members show systematic changes in substitution and chemistry.

The method has allowed several clay types to be identified, most notably saponite, montmorillonite-like clays, talc-like clays, and various mixed layer phases. Three other alteration minerals, rich in $\mathrm{Na}$ and $\mathrm{Ca}$, have been recognized chemically but remain unidentified.

In general, the findings of this study are in line with those of previous work on low-temperature alteration of basalts, such as at Holes 417A and 418A, Legs 51, 52, and 53, as described by Pritchard (1979); Pertsev and Rusinov (1979), Rusinov et al. (1979), Donnelly, Pritchard, et al. (1979), and Donnelly, Thompson, et al. (1979). 


\section{A THREE-DIMENSIONAL GRAPHICAL METHOD FOR THE CATEGORIZATION OF CLAY ANALYSES}

The structures of hydrous layered silicates, commonly known as clay minerals, are based upon continuous twodimensional sheets of $\mathrm{SiO}_{4}$ tetrahedra, individual tetrahedra linked with neighbors by sharing the three basal corners in six-fold symmetry (Bailey, 1980). The fourth tetrahedral corners (apical oxygens) all point in the same direction normal to the sheet and at the same time form part of an immediately adjacent octahedral layer in which individual octahedra are linked laterally by sharing octahedral edges. The common plane of junction between the tetrahedral and octahedral sheets consists of the shared apical oxygens plus unshared $\mathrm{OH}$ groups that lie at the center of each tetrahedral six-fold ring. The octahedral cations are normally $\mathrm{Mg}, \mathrm{Al}, \mathrm{Fe}^{2+}$, and $\mathrm{Fe}^{3+}$, but other medium-sized cations may occur in some species. The smallest structural unit contains three octahedra occupied by divalent or trivalent elements. A charge balance is achieved either when all three octahedra are occupied by divalent octahedral cations (the sheet is then classified as trioctahedral), or when two of the tetrahedra are occupied by trivalent ions and the third is vacant (the sheet is classified dioctahedral).

The layered silicates are built up of different combinations of these two types of sheet. A 2:1 layer links two tetrahedral sheets with one octahedral sheet. This requires the upper tetrahedral sheet to be inverted, so that its apical oxygens point down and can be shared with the octahedral sheet below. If the 2:1 layer is not electrostatically neutral, the excess layer charge may be neutralized by inter-layer materials, including individual cations, hydrated cations, and hydroxide octahedral groups and sheets.

The chemical composition of 2:1 layered clay varies according to the extent of cation substitution in both tetrahedral and octahedral sites, and the nature and quantity of inter-layer materials. Substitution of ions of the same valence, notably $\mathrm{Mg}-\mathrm{Fe}^{2+}$ and $\mathrm{Al}-\mathrm{Fe}^{3+}$ substitutions, are common in octahedral positions. Substitutions by ions of lesser charge, notably $\mathrm{Si}^{4+}$ by $\mathrm{Al}^{3+}$ in tetrahedral positions, and $\mathrm{Al}^{3+}$ or $\mathrm{Fe}^{3+}$ by $\mathrm{Mg}$ or $\mathrm{Fe}^{2+}$ in octahedral positions, produce negative charges on the layers which are balanced by inter-layer materials.

The principal 2:1 layered clays with their extremes of charge per formula unit $(x)$ and types of inter-layer cations are:

1) Illite group, $x=1.0$ to $1.5, \mathrm{~K}^{+}$as the principal inter-layer ion;

2) Vermiculite group, $x=0.7$ to $1.0, \mathrm{Mg}^{2+}$ and $\mathrm{Ca}^{2+}$ as the principal inter-layer ions;

3) Smectite group, $x=0.2$ to $0.7, \mathrm{Ca}^{2+}$ and $\mathrm{Na}^{+}$as the principal inter-layer ions.

The structure of 2:1 layered clays does not allow inter-layer charge to exceed 2.0, and a further constraint on composition comes from the observation that total $\mathrm{Al}+\mathrm{Fe}^{3+}$ does not exceed 6.0 atoms per formula unit (and indeed rarely approaches this level).
Dioctahedral and trioctahedral 2:1 layered clays can be considered to have the following general formulas:

$$
\begin{aligned}
& \text { Dioctahedral }\left(\mathrm{EX}^{+}\right)_{e}\left(\mathrm{Al}, \mathrm{Fe}^{3+}\right)_{m}\left(\mathrm{Mg}, \mathrm{Fe}^{2+}\right)_{4-m} \mathrm{Si}_{8-5} \mathrm{Al}_{s} \mathrm{O}_{20}(\mathrm{OH})_{4} \\
& \text { e.g., montmorillonite: }(1 / 2 \mathrm{Ca}, \mathrm{Na})_{0.66}\left(\mathrm{Al}_{3.34}, \mathrm{Mg}_{0.66}\right) \mathrm{Si}_{8} \mathrm{O}_{20}(\mathrm{OH})_{4} \\
& \text { Trioctahedral }\left(\mathrm{EX}^{+}\right)_{e}\left(\mathrm{Al}, \mathrm{Fe}^{3+}\right)_{m}\left(\mathrm{Mg}, \mathrm{Fe}^{2+}\right)_{6-m} \mathrm{Si}_{8-5} \mathrm{Al}_{s} \mathrm{O}_{20}(\mathrm{OH})_{4} \\
& \text { e.g., saponite: }(1 / 2 \mathrm{Ca}, \mathrm{Na})_{0.66} \mathrm{Mg}_{6} \mathrm{Si}_{7.34} \mathrm{Al}_{0.66} \mathrm{O}_{20}(\mathrm{OH})_{4}
\end{aligned}
$$

The exchangeable inter-layer cations are shown as monovalent ions, $\mathrm{EX}^{+}$. Structural formulas can be derived from electron-microprobe analyses in which water is not determined directly, by assuming a total cation charge of +44 in accordance with the anion complement $\mathrm{O}_{20}(\mathrm{OH})_{4}$.

Dioctahedral and trioctahedral clays may be distinguished by using their total of $\mathrm{Si}+\mathrm{Al}+\mathrm{Mg}+\mathrm{Fe}^{*}$ atoms, termed SAMF in the following discussion. With reference to formulas (1) and (2), SAMF atoms for dioctahedral and trioctahedral clays are 12 and 14, respectively. The intermediate values between these extremes represent various mixtures of di- and trioctahedral clays in amounts proportional to SAMF. For example, a clay with a SAMF of 13 would have a composition corresponding to equal amounts of di- and trioctahedral clays, which could be either regularly or irregularly inter-layered.

Alteration often proceeds in such a way as to favor the formation of mixed-layer clays in preference to pure end-member di- or trioctahedral 2:1 layered clays. Consequently, in dealing with clay analyses, a general formula summarizing all possible 2:1 layer clays, irrespective of SAMF, allows for a more realistic approach. Such a formula may be written as

$$
\left(\mathrm{EX}^{+}\right)_{e}\left(\mathrm{Al}, \mathrm{Fe}^{3+}\right)_{m}\left(\mathrm{Mg}, \mathrm{Fe}^{2+}\right)_{(4+2 t-m)} \mathrm{Si}_{8-5} \mathrm{Al}_{s} \mathrm{O}_{20}(\mathrm{OH})_{4}
$$

with

$$
\mathrm{SAMF}=m+8+(4+2 t-m)=12+2 t
$$

where $t$ is a measure of di-, trioctahedral, or intermediate character, such that $t=\mathrm{O}$ for a dioctahedral 2:1 layered clay and $t=1$ for a trioctahedral 2:1 layered clay. By determining the charge balance from formula (3),

$$
e+3 m+2(4+2 t-m)+4(8-s)-3 s=44
$$

where

$$
e=4-4 t-m+s
$$

expression (4), relating the degree of elemental substitution in octahedral and tetrahedral sites, and the interlayer charge may be deduced for all 2:1 layered clays.

Three variables have been chosen from this relationship to give the maximum information about the structure of 2:1 layered clays when plotted as a three-dimen- 
sional graph. These three variables are inter-layer charge (e), total $\mathrm{Al}+\mathrm{Fe}^{3+}(m+s)$, and SAMF as a function of $t$ in formula (4).

When $t=\mathrm{O}$ in formula (4) (dioctahedral 2:1 layered clay), a series of values for $\left(\mathrm{EX}^{+}\right)$and total $\mathrm{Al}+\mathrm{Fe}^{3+}$ can be calculated which satisfy the formula and take account of the other constraints mentioned above, that $\left(\mathrm{EX}^{+}\right) \leq 2$ and total $\mathrm{Al}+\mathrm{Fe}^{3+} \leq 6$. Graphically, these values delineate an inverted triangle (Fig. 1) enclosing a field in which dioctahedral 2:1 layered clays must fall. An opposing triangle with a common side defines the field of trioctahedral 2:1 layered clay when $t=1$ in formula (4). Several common alteration minerals have been plotted on Figure 1 to aid in orienting the graph, and fields have been outlined to show the variation and dis- tribution of members of the three groups of 2:1 layered clays.

Fields can be constructed graphically for any value of SAMF between the extremes of 12 and 14 using formula (4), each defining an area in which analyses satisfy a structural formula corresponding to a specific mixture of di- and trioctahedral clays. These fields can be displayed simultaneously using SAMF as a third axis in an isometric projection (Fig. 2).

The presentation of large numbers of clay analyses using a method which simultaneously aids in their rapid identification has been a growing problem since the electron-microprobe first became widely available. The method outlined above is a possible solution to this problem. Figure 3 is a graph of $\left(\mathrm{EX}^{+}\right)$versus total $\mathrm{Al}+\mathrm{Fe}^{3+}$ of

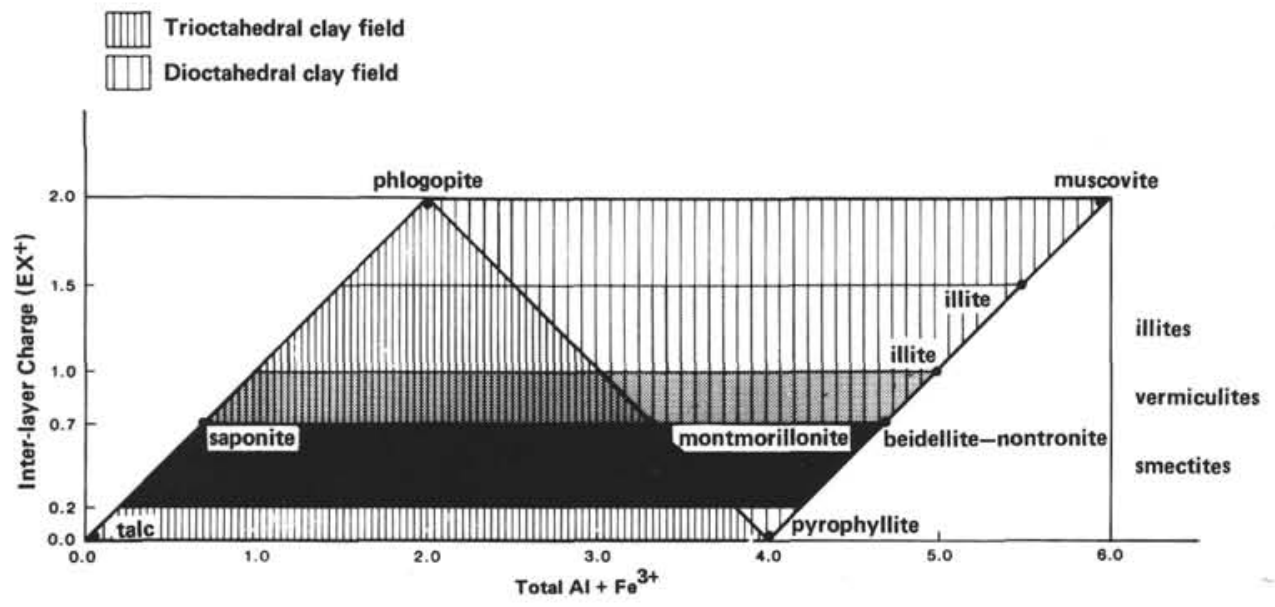

Figure 1. Fields of trioctahedral $(\mathrm{SAMF}=14)$ and dioctahedral $(\mathrm{SAMF}=12)$ 2:1 layered clays, calculated from formula (4), showing the distribution of common alteration minerals and clay groups.

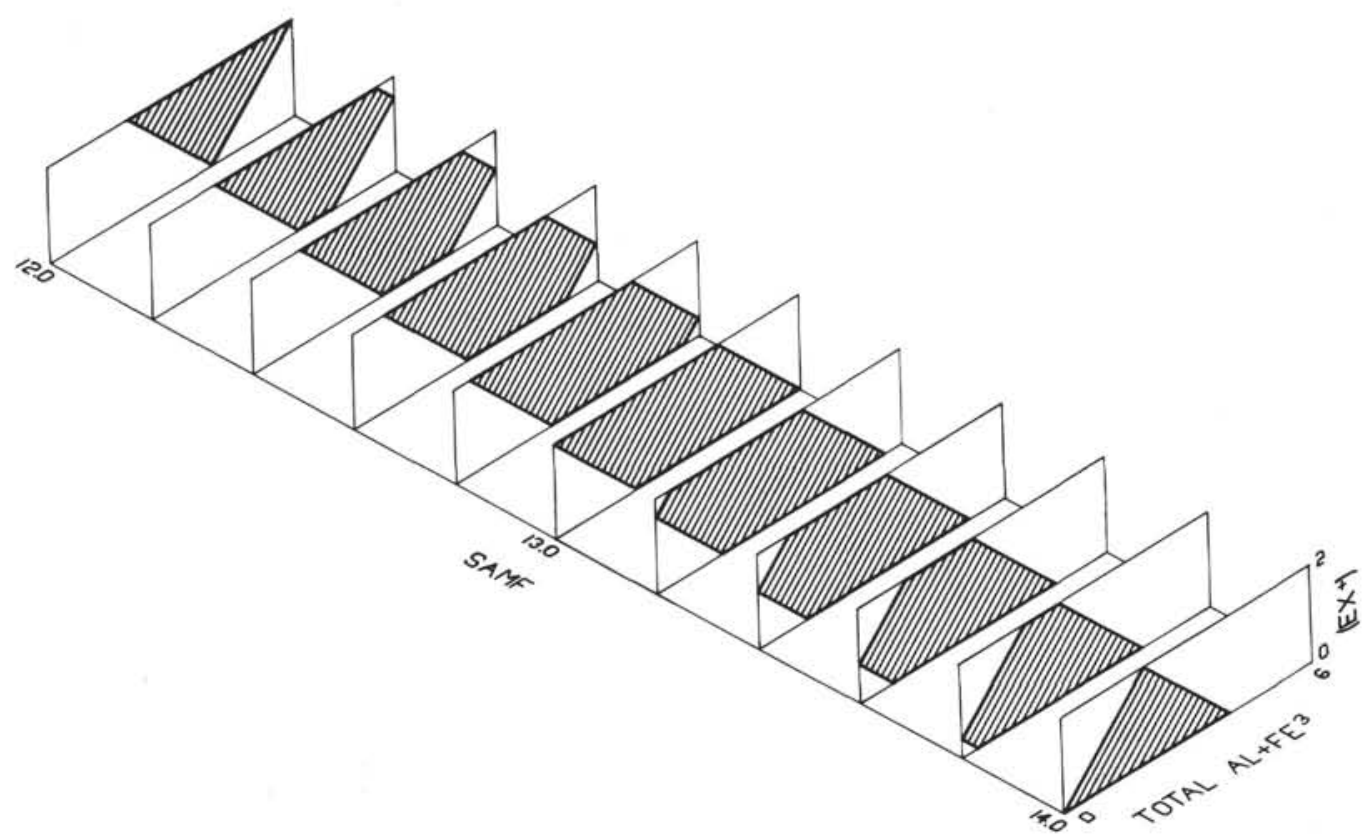

Figure 2. Three-dimensional isometric projection showing the changes in field shape and size for varying mixtures of the end-member trioctahedral and dioctahedral 2:1 layered clays. 


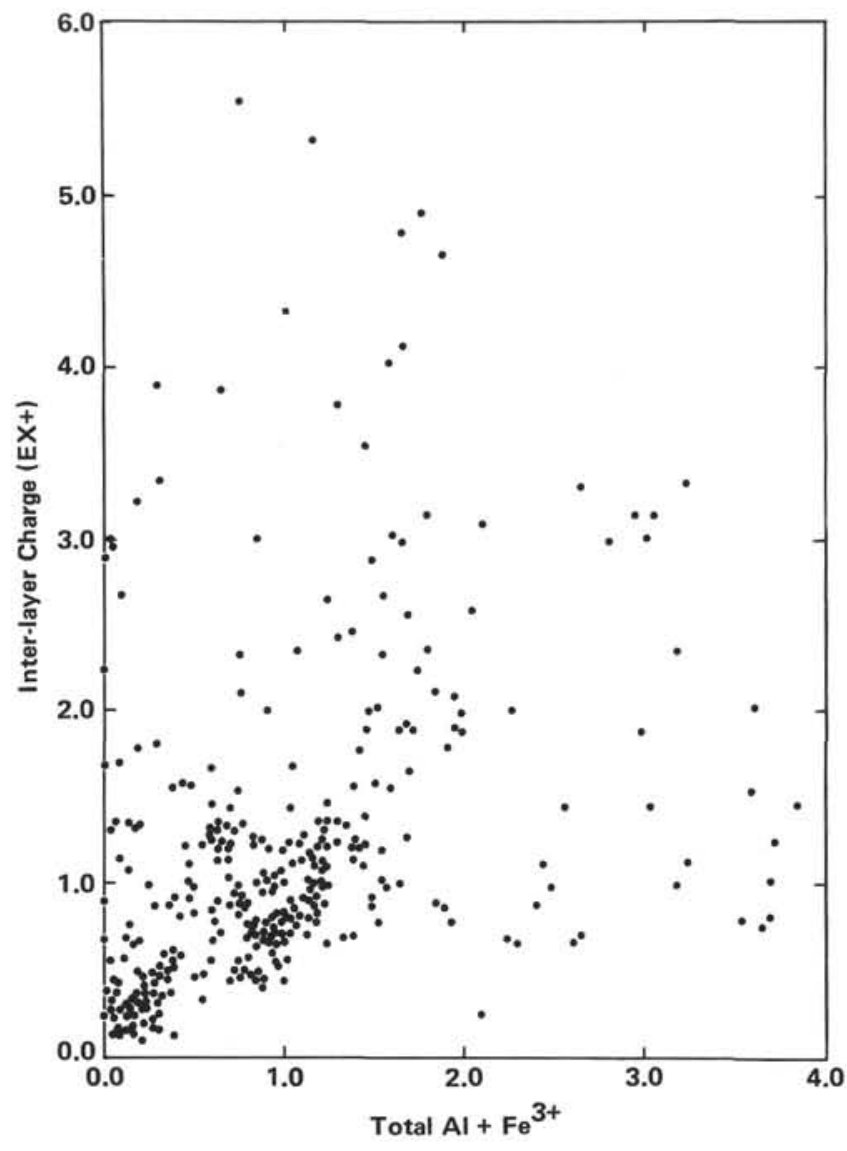

Figure 3. Characteristics of clays from Holes 504A, 504B, 505, and 505B. Relationships are obscured by the volume of data.

over 300 microprobe analyses in which the sheer volume of data obscures any relationships. Even if these were plotted as various weight percent oxides, relationships would be similarly lost. By adding a third dimension as a measure of trioctahedral character to the graph in Figure 3 , this problem can be overcome by effectively diluting the results. In addition, analyses which comprise of a variety of di- and trioctahedral clays and differing mixtures, previously indistinguishable using a two-dimensional graph, become spatially oriented and allow realistic comparisons between similar analyses. Clays which fail to satisfy the field constraints calculated for their particular value of SAMF are also evident, drawing a natural division between analyses which are 2:1 layered clays and those of some different type.

In practice, analyses are processed by computer. Oxide percents are recalculated on the basis of 22 oxygens and $\left(\mathrm{EX}^{+}\right)$, total $\mathrm{Al}+\mathrm{Fe}^{3+}$, and SAMF determined for each analysis. A program then divides the data according to SAMF, presently into eight groups between the extremes of 11.9 and 14.2 , before final plotting in a series of graphs of $\left(\mathrm{EX}^{+}\right)$versus total $\mathrm{Al}+\mathrm{Fe}^{3+}$. On each graph is a set of clusters, each composed of similar analyses (Table 1). Particularly in the case of the trioctahedral 2:1 layered clays $(\mathrm{SAMF}=14)$, division into clusters is made on the basis of structural formulas, because of the concentration of points. Dividing lines correspond to the upper and lower limits of acceptable substitution in known 2:1 layered-clay groups. Such divisions are reinforced when other graphs with an increased dioctahedral component are considered, clusters having begun to move apart (Fig. 4). For ease of pres-
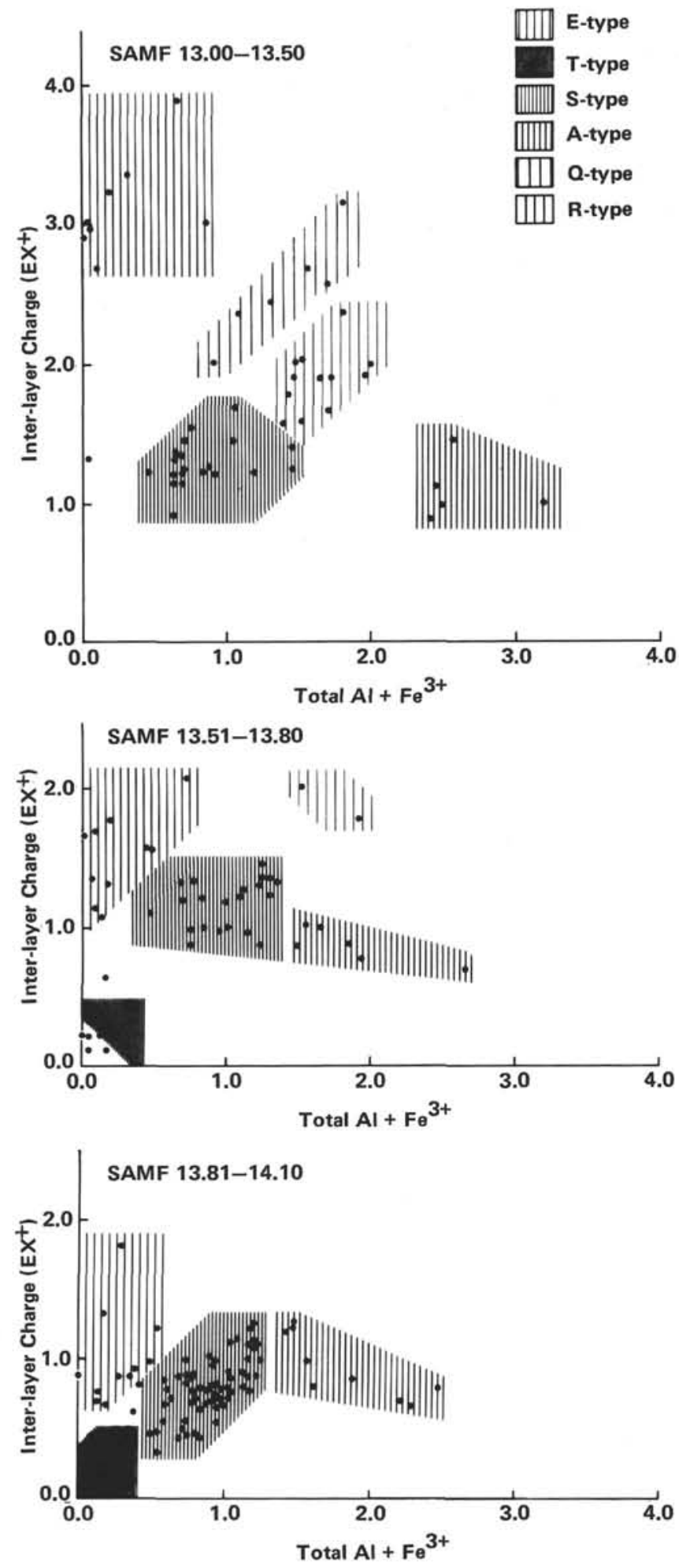

Figure 4. The same analyses as in Figure 3, divided on the basis of their SAMF values. Relationships become apparent, similar analyses forming clusters. Shaded fields are drawn on the basis of structural considerations, and are to some degree flexible. 
entation, mean compositions are calculated for each cluster (Table 2), and then plotted in a three-dimensional isometric projection (Fig. 5). The result is a series of trends, their position within the projection a function of composition and clay type (Fig. 1). Direction indicates systematic changes in inter-layer charge and octahedral and tetrahedral substitution with changing SAMF.

Unfortunately, a three-dimensional projection such as this is inherently difficult to use for determining the coordinate values for a point in space. To overcome this problem, a standard graph of $\left(\mathrm{EX}^{+}\right)$versus total $\mathrm{Al}+$ $\mathrm{Fe}^{3+}$ (Fig. 6) is used in conjunction with a three-dimensional projection, both allowing easy reading of values and providing information on spatial relationships.

\section{OXIDATION STATE OF IRON}

The oxidation state of the iron has a marked effect on the calculation of total $\mathrm{Al}+\mathrm{Fe}^{3+}$, and a less-marked effect on other parameters. It cannot be determined by the electron microprobe, and in calculating structural formulas it must be assumed. Wet chemical analyses of some samples of clay from Leg 69 give $\mathrm{Fe}^{2+}: \mathrm{Fe}^{3+}$ ratios of about 1 , though there are samples from oxidized zones in which $\mathrm{Fe}^{3+}$ is dominant (Pertsev and Boronikhin, this volume). Nevertheless, the calculations here have been made with $\mathrm{Fe}$ entirely taken as ferrous iron for the sake of simplicity and comparability.

Though the effect of this is small when iron concentrations are low, it becomes important for iron-rich clays. For typical samples of clays analyzed here, with total $\mathrm{Fe}$ about 1.2 atoms per formula unit, oxidation of all of the iron would decrease $\mathrm{EX}^{+}, \mathrm{SAMF}$, and total $\mathrm{Al}$ by about $3 \%$ relative, and would decrease $\left(\mathrm{Mg}+\mathrm{Fe}^{2+}\right)$ and increase (total $\mathrm{Al}+\mathrm{Fe}^{3+}$ ) by the amount of iron involved (Table 3). The result on Figure 5 is to displace points to the right and slightly downward. The effect on many analyses is small, but it may bring some analyses plotting to the left of the field of 2:1 clay minerals so that they plot within it. This effect should be remembered when using Figure 5.

\section{SECONDARY MINERALS}

\section{Clays}

In hand specimen, the clays are of various shades of green, lining or completely filling vesicles and veins, replacing olivine and glass in both chilled pillow margins and interstitial areas, and acting as cement to basaltic breccias. In zones of intense oxidation, red, orange, or yellow clays often envelope, partially or completely, green smectite cores. Crystallization of carbonates or various zeolites was a final phase of secondary-mineral formation: these phases form the centers of veins and vesicles, and more rarely pseudomorphs. Clays are of several different morphological types. Fibrous varieties are composed of a mass of elongate crystals which generally grow perpendicular to fracture walls or around nuclei to form radiating fans and spheres. Layered forms comprise of a series of different-colored clay bands closely following the contours of the basalt walls.
Granular varieties appear mottled, composed of clays of a single color but of differing shades. Amorphous forms show no structure; they are usually dark in hand specimen and opaque when viewed in thin-section.

In thin-section, clays are usually various shades of brown and green, but may be yellow, orange, and red in oxidized zones. Clay morphologies in thin-section vary in the same way as in hand specimen. Several different forms in a single vein can be used as indicators of the conditions prevailing at time of precipitation. It would seem reasonable to suppose that good crystal shape develops under stable and prolonged conditions of free uninhibited growth, and irregular crystal forms under conditions favoring more rapid formation. Layering, particularly in veins, must be a consequence of fluid fluctuations during clay precipitation, and, though optically apparent, internal geochemical variations are often absent. Combinations of the various morphologies often allow for the determination of a complex crystallization history, which is then capable of being investigated geochemically.

In particularly large cavities and veins, clays form isolated, radiating spheres, occasionally showing layering. These eventually merge when in sufficient abundance to form an amorphous or plumose mass. This radiating morphology would suggest free growth around a nucleus, probably in the form of small fragments from clay-coated walls.

Clays forming olivine pseudomorphs follow a characteristic veining pattern as a result of the initial alteration down cracks. Depending on local conditions, clays are either highly birefringent fibrous varieties, occasionally containing blebs rich in sodium and calcium, or dark, isotropic forms.

The alteration of glass varies in intensity between different areas of the core, but in general pale-brown or green clays replace pillow margins with veining by zeolites, and darker clays interstitial glass, unless stained bright orange in oxidized areas. The alteration of glass is an in situ process, and the minerals which are formed are fundamentally different from those produced by precipitation in veins and vesicles. Geochemically, the majority are from a single montmorillonite-like minerals group rich in the less-mobile elements such as $\mathrm{Al}$ and $\mathrm{Ti}$. In contrast, the clays precipitated in veins and vesicles are more varied in their composition and clay type.

\section{Geochemistry}

Geochemically, these analyses form six distinct trends when plotted on a three-dimensional graph using the method and techniques described earlier (Figs. 5 and 6).

The geochemistry and petrological significance of these six groups will be considered in two sections, the first covering the $2: 1$ clay types $\mathrm{T}$ (talc), $\mathrm{S}$ (saponite), and $\mathrm{A}$ (montmorillonite-like minerals), and the second, clay mixtures containing an end-member component with an unknown compositional formula (here labelled R, Q, and $\mathrm{E}$ minerals, as described below). 
Table 1. Selected microprobe analyses of clay minerals from Holes 504A, 504B, 505, and 505B.

\begin{tabular}{|c|c|c|c|c|c|c|c|c|c|c|c|c|}
\hline $\begin{array}{l}\text { Analysis No. } \\
\text { Sample } \\
\text { (interval in cm) }\end{array}$ & $\begin{array}{c}310 \\
505 \mathrm{~B}-2-1 \\
25-28\end{array}$ & $\begin{array}{c}173 \\
505 \mathrm{~B}-2-2 \\
100-103\end{array}$ & $\begin{array}{c}453 \\
504 \mathrm{~B}-40-2 \\
89-91\end{array}$ & $\begin{array}{c}307 \\
505 \mathrm{~B}-2-1, \\
25-28\end{array}$ & $\begin{array}{c}349 \\
505 \mathrm{~B}-3-1 \\
109-112\end{array}$ & $\begin{array}{c}356 \\
505 \mathrm{~B}-3-1 \\
109-112\end{array}$ & $\begin{array}{c}289 \\
504 \mathrm{~B}-61-3, \\
1-4\end{array}$ & $\begin{array}{c}440 \\
504 \mathrm{~B}-63-4 \\
65-69\end{array}$ & $\begin{array}{c}403 \\
505 \mathrm{~B}-5-1 \\
50-60\end{array}$ & $\begin{array}{c}239 \\
504 \mathrm{~B}-58-1, \\
35-38\end{array}$ & $\begin{array}{c}135 \\
504 \mathrm{~B}-21-4, \\
120-124\end{array}$ & $\begin{array}{c}30 \\
504 \mathrm{~B}-7-3, \\
27-30\end{array}$ \\
\hline Type $^{\mathrm{a}}$ & $E_{2}$ & $E_{2}$ & $E_{3}$ & $E_{3}$ & $\mathrm{~T}_{0}$ & $\mathrm{~T}_{0}$ & $\mathrm{~T}_{1}$ & $\mathrm{~T}_{1}$ & $\mathrm{~T}_{1}$ & $\mathrm{~S}_{0}$ & $\mathrm{~S}_{0}$ & $\mathrm{~S}_{1}$ \\
\hline $\begin{array}{l}\mathrm{SiO}_{2} \\
\mathrm{TiO}_{2}\end{array}$ & 56.90 & 46.80 & 49.30 & 54.20 & 46.30 & 43.60 & 54.40 & 55.50 & 54.10 & 39.40 & 45.80 & 47.80 \\
\hline $\begin{array}{l}\mathrm{Al}_{2} \mathrm{O}_{3} \\
\mathrm{FeO} \\
\mathrm{MnO}\end{array}$ & $\begin{array}{l}0.66 \\
6.40\end{array}$ & 26.20 & $\begin{array}{l}4.06 \\
8.10\end{array}$ & 6.00 & $\begin{array}{r}1.23 \\
20.10\end{array}$ & $\begin{array}{r}1.33 \\
19.80\end{array}$ & $\begin{array}{r}1.67 \\
14.20\end{array}$ & $\begin{array}{r}1.20 \\
10.90\end{array}$ & $\begin{array}{c}0.81 \\
9.50\end{array}$ & $\begin{array}{r}5.81 \\
18.20\end{array}$ & $\begin{array}{l}5.06 \\
8.90\end{array}$ & $\begin{array}{r}5.72 \\
11.20\end{array}$ \\
\hline $\begin{array}{l}\mathrm{MgO} \\
\mathrm{CaO} \\
\mathrm{Na}_{2} \mathrm{O} \\
\mathrm{K}_{2} \mathrm{O}\end{array}$ & $\begin{array}{r}26.41 \\
0.10 \\
3.95 \\
0.30\end{array}$ & $\begin{array}{l}9.19 \\
0.36 \\
7.64 \\
2.62\end{array}$ & $\begin{array}{r}23.21 \\
1.20 \\
13.14 \\
0.27\end{array}$ & $\begin{array}{r}26.10 \\
0.15 \\
10.62 \\
0.28\end{array}$ & $\begin{array}{r}17.19 \\
0.39 \\
1.99 \\
1.34\end{array}$ & $\begin{array}{r}13.80 \\
0.34 \\
0.79 \\
0.18\end{array}$ & $\begin{array}{r}20.17 \\
1.13 \\
0.18\end{array}$ & $\begin{array}{r}23.09 \\
0.80 \\
0.12\end{array}$ & $\begin{array}{r}22.08 \\
0.22 \\
0.29\end{array}$ & $\begin{array}{r}13.95 \\
2.13 \\
0.57\end{array}$ & $\begin{array}{r}20.96 \\
0.70 \\
0.94 \\
0.25\end{array}$ & $\begin{array}{r}20.52 \\
0.69 \\
1.37 \\
0.51\end{array}$ \\
\hline Total & 94.73 & 92.83 & 99.30 & 97.30 & 88.57 & 81.65 & 91.74 & 91.58 & 87.21 & 80.29 & 82.61 & 87.86 \\
\hline $\begin{array}{l}\mathrm{Si} \\
\mathrm{Al} \\
\mathrm{Al} \\
\mathrm{Ti}\end{array}$ & $\begin{array}{l}7.64 \\
0.10\end{array}$ & 7.43 & $\begin{array}{l}6.72 \\
0.65\end{array}$ & 7.32 & $\begin{array}{l}7.26 \\
0.23\end{array}$ & $\begin{array}{l}7.48 \\
0.27\end{array}$ & $\begin{array}{l}7.72 \\
0.28\end{array}$ & $\begin{array}{l}7.75 \\
0.20\end{array}$ & $\begin{array}{l}7.87 \\
0.14 \\
0.01\end{array}$ & $\begin{array}{l}6.75 \\
1.17\end{array}$ & $\begin{array}{l}7.14 \\
0.93\end{array}$ & $\begin{array}{l}7.09 \\
0.91 \\
0.09\end{array}$ \\
\hline $\begin{array}{l}\mathrm{Fe}^{2+} \\
\mathrm{Mn}\end{array}$ & 0.72 & 3.47 & 0.92 & 0.68 & 2.63 & 2.84 & 1.68 & 1.27 & 1.16 & 2.61 & 1.16 & 1.38 \\
\hline $\mathrm{Mg}$ & 5.28 & 2.17 & 4.71 & 5.26 & 4.01 & 3.53 & 4.27 & 4.80 & 4.78 & 3.56 & 4.87 & 4.54 \\
\hline $\mathrm{Ca}$ & 0.01 & 0.61 & 0.17 & 0.02 & 0.07 & 0.06 & 0.17 & 0.12 & 0.03 & 0.39 & 0.19 & 0.11 \\
\hline $\begin{array}{l}\mathrm{Na} \\
\mathrm{K}\end{array}$ & $\begin{array}{l}1.03 \\
0.05\end{array}$ & $\begin{array}{l}2.35 \\
0.53\end{array}$ & $\begin{array}{l}3.47 \\
0.05\end{array}$ & $\begin{array}{l}2.78 \\
0.05\end{array}$ & $\begin{array}{l}0.60 \\
0.27\end{array}$ & $\begin{array}{l}0.26 \\
0.04\end{array}$ & 0.03 & 0.02 & 0.05 & 0.19 & $\begin{array}{l}0.28 \\
0.05\end{array}$ & $\begin{array}{l}0.39 \\
0.10\end{array}$ \\
\hline $\begin{array}{l}\text { Mean SAMF } \\
\text { Total } \mathrm{Al}+\mathrm{Fe}^{3+} \\
\left(\mathrm{EX}^{+}\right) \\
\left(\mathrm{Mg}+\mathrm{Fe}^{2+}\right)\end{array}$ & $\begin{array}{r}13.77 \\
0.10 \\
1.11 \\
6.00\end{array}$ & $\begin{array}{l}3.00 \\
5.64\end{array}$ & $\begin{array}{r}13.01 \\
0.65 \\
3.87 \\
5.64\end{array}$ & $\begin{array}{l}2.87 \\
5.93\end{array}$ & $\begin{array}{r}14.13 \\
0.23 \\
1.00 \\
6.64\end{array}$ & $\begin{array}{r}14.12 \\
0.27 \\
0.43 \\
6.37\end{array}$ & $\begin{array}{r}13.95 \\
0.28 \\
0.37 \\
5.95\end{array}$ & $\begin{array}{r}14.02 \\
0.20 \\
0.26 \\
6.07\end{array}$ & $\begin{array}{r}13.95 \\
0.14 \\
0.12 \\
5.94\end{array}$ & $\begin{array}{r}14.10 \\
1.17 \\
0.97 \\
6.17\end{array}$ & $\begin{array}{r}14.11 \\
0.93 \\
0.57 \\
6.04\end{array}$ & $\begin{array}{r}14.01 \\
1.00 \\
0.71 \\
5.92\end{array}$ \\
\hline
\end{tabular}

${ }^{a}$ Letters refer to mineral type (see text); subscript numbers indicate the SAMF division to which the analysis is assigned, as follows: 6 , SAMF < 12.00; $5,12.00-12.50$; $4,12.51-$ $13.00 ; 3,13.01-13.50 ; 2,13.51-13.80 ; 1,13.81-14.10 ; 0$, SAMF $<14.10$.

\section{2:1 Clay Minerals}

\section{Talc-like Minerals}

The graphical position of pure talc, with compositional formula $\mathrm{Mg}_{6} \mathrm{Si}_{8} \mathrm{O}_{20}(\mathrm{OH})_{4}$, is shown in Figure 1 . The 31 analyses representing the clay types $T_{1}$ are chemically very close to this ideal composition, and can almost be considered as pure talc. They have an average SAMF of 14, and a formula only slightly different from that of the pure mineral,

$$
\left(\mathrm{EX}^{+}\right)_{0.3}\left(\mathrm{Mg}, \mathrm{Fe}^{2+}\right)_{6} \mathrm{Si}_{7.7} \mathrm{Al}_{0.3} \mathrm{O}_{20}(\mathrm{OH})_{4} \text {. }
$$

This difference arises from the limited substitution of silica by aluminium in tetrahedral sites, and by a corresponding small increase in the inter-layer charge.

Although the chemistry of $T_{1}$ minerals is similar to that of talc, no talc has been identified positively by means of XRD in these rocks. In addition, no optical identification has been confirmed during this study. Possibly these analyses are of an unusual mineral type with a very poor exchangeable-cation capacity.

A line connecting $T_{0}, T_{1}$, and $T_{2}$ (Fig. 5) indicates the approximate plotting position of any analysis with a talc-like composition between possible extremes of SAMF. A lower limit of SAMF $=13.6$ is evident from available analyses; below this, talc-like minerals would appear not to form. In the case of the $T_{0}$ analyses, an average SAMF of 14.3 is above the maximum for a trioctahedral clay. These analyses are minerals poor in exchangeable cations, but rich in the cations of which SAMF is a measure.

Particularly in the case of the $\mathrm{T}_{1}$ analyses, separation from the more-saponitic minerals, $\mathrm{S}_{1}$, has been made on the basis of structural formulas, allowing a certain flexibility in the position of the dividing line. Analyses close to this line may well be mixtures of talc-like minerals and saponites in varying proportions. Once SAMF has decreased to around 13.8 , clusters have diverged sufficiently to eliminate any such trend (Fig. 4).

Talc-like minerals are most common as the alteration product of olivine, particularly in the lower section of Hole 504B. A few examples are present at Site 505, but generally the olivine is reasonably fresh here compared to other sites. Most pseudomorphs are homogeneous in composition. Only one heterogeneous olivine pseudomorph has been found containing talc-like minerals mixed with other phases (Sample 504B-41-2, Piece 605). In vesicles, minerals other than the talc-like phases are often present, acting as either rims or cores.

\section{Saponites}

Clays with a compositional formula corresponding to that of saponite, or some variant of its basic formula, are by far the most common alteration minerals present in basalts from the Costa Rica Rift.

Trioctahedral saponites in these rocks, $\mathrm{S}_{1}$, have a derived formula,

$$
\left(\mathrm{EX}^{+}\right)_{0.77}\left(\mathrm{Mg}, \mathrm{Fe}^{2+}\right)_{6.0} \mathrm{Si}_{7.1} \mathrm{Al}_{0.9} \mathrm{O}_{20}(\mathrm{OH})_{4} \text {. }
$$

They differ only slightly from an ideal saponite, where substitution in both inter-layer and tetrahedral sites is 0.66. In the other S-type minerals conforming to this basic formula, substitution by aluminium in octahedral sites becomes more pronounced as SAMF values decrease, and the dioctahedral component of mixtures becomes dominant. The increase in inter-layer charge from 
Table 1. (Continued).

\begin{tabular}{|c|c|c|c|c|c|c|c|c|c|c|c|c|}
\hline 242 & 408 & 369 & 121 & 933 & 921 & 286 & 112 & 203 & 155 & 232 & 924 & 222 \\
\hline $\begin{array}{c}504 \mathrm{~B}-58-1 \\
35-38\end{array}$ & $\begin{array}{c}504 \mathrm{~B}-36-2 \\
121-123\end{array}$ & $\begin{array}{c}504 \mathrm{~B}-54-1 \\
31-34\end{array}$ & $\begin{array}{c}504 \mathrm{~A}-6-3 \\
12-15\end{array}$ & $\begin{array}{c}504 \mathrm{~B}-14-2 \\
1-17\end{array}$ & $\begin{array}{c}504 \mathrm{~B}-9-2, \\
11-14\end{array}$ & $\begin{array}{c}504 \mathrm{~B}-49-1, \\
51-54\end{array}$ & $\begin{array}{c}504 \mathrm{~A}-6-3 \\
12-15\end{array}$ & $\begin{array}{c}504 \mathrm{~B}-7-2 \\
98-102\end{array}$ & $\begin{array}{c}504 \mathrm{~B}-37-1, \\
15-17\end{array}$ & $\begin{array}{c}504 \mathrm{~B}-69-1, \\
106-112\end{array}$ & $\begin{array}{c}504 \mathrm{~B}-6-1, \\
33-43\end{array}$ & $\begin{array}{c}504 \mathrm{~B}-28-5, \\
19-22\end{array}$ \\
\hline $\mathrm{S}_{1}$ & $\mathrm{~s}_{1}$ & $S_{2}$ & $\mathrm{~S}_{2}$ & $\mathrm{~S}_{2}$ & $\mathrm{~S}_{3}$ & $\mathrm{~S}_{3}$ & $\mathrm{~S}_{3}$ & $A_{1}$ & $\mathrm{~A}_{1}$ & $A_{1}$ & $\mathbf{R}_{3}$ & $\mathbf{R}_{3}$ \\
\hline \multirow[t]{2}{*}{41.50} & 48.80 & 48.70 & 52.10 & 50.80 & 49.50 & 48.00 & 52.90 & 44.90 & 44.50 & 43.90 & 48.80 & 43.20 \\
\hline & 0.13 & & & 0.27 & 0.39 & & & 0.25 & & & 0.35 & 0.88 \\
\hline 6.33 & 3.38 & 7.68 & 4.49 & 7.08 & 8.66 & 5.95 & 3.77 & 13.32 & 7.78 & 8.53 & 8.76 & 9.03 \\
\hline 17.60 & 14.90 & 14.40 & 14.80 & $\begin{array}{r}10.90 \\
0.08\end{array}$ & $\begin{array}{r}10.90 \\
0.08\end{array}$ & 16.90 & 17.80 & $\begin{array}{r}16.90 \\
0.19\end{array}$ & 7.60 & 16.50 & $\begin{array}{r}10.60 \\
0.12\end{array}$ & 23.80 \\
\hline 15.23 & 18.38 & 18.87 & 16.08 & 20.33 & 16.35 & 14.90 & 13.42 & 12.56 & 21.30 & 15.60 & $\begin{array}{r}0.12 \\
17.58\end{array}$ & 9.41 \\
\hline 2.81 & 1.63 & 3.14 & 1.23 & 1.81 & 1.80 & 3.35 & 1.07 & 0.85 & 2.67 & 2.60 & 4.49 & 2.67 \\
\hline 0.76 & 0.93 & 1.70 & 1.14 & 1.73 & 1.94 & 0.72 & 0.96 & & 0.89 & 0.47 & 1.88 & 3.39 \\
\hline 0.10 & 0.22 & 0.18 & 1.85 & 0.09 & 1.02 & 2.26 & 1.53 & 1.97 & 0.26 & 0.13 & 0.16 & 0.27 \\
\hline 84.65 & 88.38 & 94.72 & 91.75 & 93.10 & 90.65 & 92.35 & 91,46 & 90.91 & 84.98 & 87.80 & 92.97 & 92.66 \\
\hline 6.71 & 7.33 & 6.85 & 7.54 & 7.09 & 7.12 & 7.09 & 7.74 & 6.63 & 6.76 & 6.74 & 6.90 & 6.61 \\
\hline \multirow{3}{*}{1.21} & 0.60 & 1.27 & 0,46 & 0.91 & 0.88 & 0.91 & 0.26 & 0.14 & 1.24 & 1.26 & 1.10 & 1.39 \\
\hline & & & 0.30 & 0.97 & 0.59 & 0.13 & 0.39 & 2.18 & 0.15 & 0.28 & 0.36 & 0.24 \\
\hline & 0.01 & & & 0.03 & 0.04 & & & & & & 0.04 & 0.10 \\
\hline \multirow[t]{2}{*}{2.38} & 1.88 & 1.70 & 1.79 & 1.27 & 1.31 & 2.09 & 2.18 & 2.09 & 0.97 & 2.11 & 1.26 & 3.04 \\
\hline & & & & 0.01 & 0.01 & & & 0.03 & & & 0.01 & \\
\hline 3.67 & 4.12 & 3.96 & 3.46 & 4.23 & 3.50 & 3.28 & 2.96 & 2.77 & 4.83 & 3.58 & 3.70 & 2.14 \\
\hline 0.49 & 0.26 & 0.47 & 0.19 & 0.27 & 0.28 & 0.53 & 0.18 & 0.14 & 0.44 & 0.43 & 0.68 & 0.44 \\
\hline 0.24 & 0.27 & 0.46 & 0.32 & 0.47 & 0.54 & 0.21 & 0.27 & & 0.26 & 0.14 & 0.52 & 1.00 \\
\hline 0.02 & 0.04 & 0.03 & 0.34 & 0.17 & 0.19 & 0.43 & 0.29 & 0.37 & 0.05 & 0.03 & 0.23 & 0.05 \\
\hline 13.97 & 13.92 & 13.79 & 13.56 & 13.75 & 13.41 & 13.49 & 13.49 & 13.80 & 13.95 & 13.98 & 13.32 & 13.41 \\
\hline 1.21 & 0.60 & 1.27 & 0.76 & 1.16 & 1.47 & 1.03 & 0.65 & 2.32 & 1.39 & 1.54 & 1.46 & 1.63 \\
\hline 1.24 & 0.84 & 1.44 & 1.04 & 1.03 & 1.28 & 1.69 & 0.89 & 0.64 & 1.19 & 1.02 & 1.90 & 1.93 \\
\hline 6.05 & 5.99 & 5.66 & 5.56 & 5.50 & 4.82 & 5.37 & 5.10 & 4.85 & 5.79 & 5.70 & 4.96 & 5.18 \\
\hline
\end{tabular}

$\mathrm{S}_{1}$ to $\mathrm{S}_{4}$ (Table 1) is principally due to an increase in $\mathrm{K}^{+}$ content.

Unlike the talc-like minerals, different saponites commonly occur together, and they exhibit a wide range of morphologies irrespective of their location. They occupy the complete spectrum of alteration sites: veins, vesicles, pseudomorphs, matrix, and marginal glass areas. In many cases, saponites filling vesicles and veins are stratified with interleaved layers of other mineral types. There appears to be no relationship linking the order in which layers of different chemistry occur, except that SAMF values are often lower in border areas than in the central parts of veins and vesicles. In several cases, saponite-filled vesicles have a core composed of $\mathrm{S}_{1}$ clays and a rim of $\mathrm{S}_{3}$, a transition requiring a decrease in SAMF but an increase of $\mathrm{K}^{+}$in inter-layer sites.

\section{Montmorillonite-like Minerals}

The clay analyses belonging to this series can be divided into two groups, one resembling a very aluminous saponite $\left(A_{1}-A_{3}\right)$, and the other more akin to an ideal montmorillonite mineral $\left(\mathrm{A}_{4}-\mathrm{A}_{6}\right)$ (Table 2$)$.

In the first group $\left(A_{1}-A_{3}\right)$, the increases in aluminium are accommodated in octahedral sites. It would seem highly probable that the analyses belonging to types $A_{1}$ and $\mathrm{A}_{2}$, are mixtures of saponites and the montmorillonite-like minerals, $\mathbf{A}_{4}-\mathrm{A}_{6}$, in varying proportions. Distinct clusters are evident of particular mixtures, however, and I feel that these warrant treatment as separate groups. In the second A-type group $\left(\mathbf{A}_{4}-\mathbf{A}_{6}\right)$, analyses resemble ideal montmorillonite and plot well away from saponitic minerals, mixing of the two having finished with the $A_{2}$ minerals. The closest any of these analyses comes to an ideal montmorillonite is:

$$
\left(\mathrm{EX}^{+}\right)_{0.9}\left(\mathrm{Al}, \mathrm{Fe}^{3+}, \mathrm{Ti}\right)_{2.7}\left(\mathrm{Mg}, \mathrm{Fe}^{2+}, \mathrm{Mn}\right)_{1.5} \mathrm{Si}_{7.1} \mathrm{Al}_{0.9} \mathrm{O}_{20}(\mathrm{OH})_{4}
$$

There are significant amounts of titanium and manganese in these analyses.

The purer dioctahedral clay members of this series, notably $A_{4}-A_{6}$, rich in the less-mobile elements such as $\mathrm{Al}$ and $\mathrm{Ti}$, are formed by the in situ alteration of glass, principally in pillow margins. There are no occurrences of these minerals constituting pseudomorphs, and only rare instances as fillings of vesicles. Altered glass margins are often composed of a series of fragments formed during cooling, separated by layered veins. The fragments are optically layered, but chemically are relatively homogeneous, composed entirely of aluminous clays of types $\mathbf{A}_{4}$ and $\mathbf{A}_{5}$. The veins are more diverse, composed of a variety of clay types. The most common are the minerals $A_{1}-A_{3}$, but there are occasional layers of saponite, $S_{1}$, and rare phases such as $R_{3}$. The association of saponite with $A_{1}-A_{3}$ minerals illustrates the mixing between these groups, discussed earlier. Saponites precipitated in the marginal areas of veins adjacent to montmorillonite-like clays of types $\mathbf{A}_{4}-\mathbf{A}_{6}$ would appear to have an effect of locally diluting these to form minerals of types $\mathbf{A}_{1}-\mathbf{A}_{3}$. Formation of zeolites in the central parts of veins is the final phase of precipitation.

Microprobe analyses of altered interstitial matrix glass away from areas of intense replacement shows alteration processes to be similar to those active within pillow margins, favoring formation of aluminum-rich clays. These are mainly $A_{1}$ and $A_{2}$-type clays, but a few $S_{1}$ saponites and rare $\mathrm{R}$ - and E-type minerals occur.

\section{Non-2:1 Clay Minerals}

The three secondary mineral series designated $\mathrm{E}, \mathrm{Q}$, and $R$ are not 2:1 layered clays, but may represent either mixtures of various 2:1 layered clays with an end member of uncertain composition, or alternatively a separate series of secondary clay minerals, different from 2:1 
layered clays, but with their own characteristics and trends.

\section{Group R Minerals}

This group contains analyses which appear to represent varying mixtures of a 2:1 layered clay and an unidentified mineral of $\mathrm{R}_{5}$ type, rich in $\mathrm{Na}$ and $\mathrm{Ca}$. Interlayer charge is characteristically high, exceeding 2 in the case of the mineral types $\mathbf{R}_{4}$ and $\mathbf{R}_{5}$. Analyses forming the two types $R_{2}$ and $R_{3}$ have an inter-layer charge close to 2 , and although chemically they meet the requirements for a 2:1 layered clay, derived compositional formulas resemble no common 2:1 layered clay mineral.

Analyses belonging to this series are not common and are restricted to vein and vesicle fillings and to undefined matrix material in intensely altered breccias. The two mineral types $R_{2}$ and $R_{3}$, which resemble clays, are found exclusively as layers in vesicles and very occasionally in veins. They can act as the outer rim of a layered series, saponite $\left(\mathrm{S}_{1}-\mathrm{S}_{3}\right)$ and talc forming the core. The analyses which correspond to types $R_{4}$ and $R_{5}$ are from breccias and amorphous isotropic areas of alteration in the basalt matrix. It seems probable that in such cases contamination by varying amounts of whole rock may have occurred.

\section{Group Q Minerals}

The main characteristic of this group is the very high concentration of inter-layer charge, which excludes them from being 2:1 layered clays. Calcium is an important component, varying from 7 to 14 oxide percent in types $\mathrm{Q}_{3}$ and $\mathrm{Q}_{5}$, respectively, considerably more than in any other alteration mineral found in these rocks. The amounts of aluminum and silica fluctuate only slightly throughout the series; the decrease in SAMF results from an overall decrease in magnesium and iron, but follows no simple pattern. Iron can increase at the expense of magnesium or vice versa, while still maintaining an overall decrease in their totals from $\mathrm{Q}_{3}$ to $\mathrm{Q}_{5}$.

Minerals with this chemistry occur in veins, pseudomorphs, and vesicles. In the case of the latter, no layering is evident, the vesicle apparently being filled by a single phase. Other vesicles in the same sample may contain different clay minerals; the saponite type $S_{1}$, for example, can be found in close proximity to minerals of type Q.

When these minerals are one of several phases filling a pseudomorph, some interesting relationships occur. Generally they form isolated blebs in the center of highly birefringent clays of different chemistry, principally saponites and talcs. Blebs are usually composed of one of the two mineral types $\mathrm{Q}_{4}$ and $\mathrm{Q}_{5}$, but in one case an envelope of $E_{5}$ has formed. The latter is a highly sodic mineral. If the blebs are a later phase of alteration, then the process which differentially concentrates calcium into these small areas, and iron in the case of $\mathrm{Q}_{4}$, apparently does not affect surrounding talcs or saponites. Possibly they are the products of a process of differentiation or segregation operative during simultaneous formation of the two phases, magnesium preferen- tially being absorbed into saponite or talc minerals, and calcium, and to a lesser extent aluminium, into the blebs.

Two examples of olivine pseudomorphs completely filled by secondary minerals of composition $\mathrm{Q}_{4}$ have been recorded. They are opaque in thin-section, probably a result of their high iron content.

\section{Group E Minerals}

The most notable characteristic of the analyses forming this group, is their diversity in sodium content from one end of the series to the other. Expressed as oxide percents, sodium forms only 0.6 of the $\mathrm{E}_{0}$ mineral analyses, but increases to 14.0 in the case of mineral $E_{5}$.

If iron in these analyses is assumed to be completely reduced, the $\mathrm{E}_{0}-\mathrm{E}_{3}$ minerals with an inter-layer charge less than 2 (Figs. 5 and 6 ) fail to satisfy the field requirements for 2:1 layered clays, and therefore must be structurally of some different mineral type. However, once some degree of partial oxidation is assumed in the $\mathrm{E}_{0}-\mathrm{E}_{3}$ minerals, spatial movement is sufficient to bring these analyses within the 2:1 layered clay fields. Although structurally these analyses then conform to the requirements for a 2:1 layered clay, their derived formulas do not resemble any common clay mineral.

Analyses of the two most sodic members of the series are presently limited to one of each. Exchangeable cations far exceed the acceptable maximum for clays, and a ratio of $(\mathrm{Na}+\mathrm{K}):(\mathrm{Mg}+\mathrm{Fe}): \mathrm{Si}$ is probably the most useful means of illustrating relative element abundances for comparison with the other mineral groups. In the case of the mineral $E_{4}$, this ratio is $4: 6: 7$, and for $E_{5}$ it is $6: 6: 6.5$. Whether these two analyses represent an endmember mineral which is mixed in varying proportions with 2:1 layered clays to form the E-type trend is unclear at this time.

Members of the group with low inter-layer charge, $E_{1}-E_{3}$, when occurring together, form a continuous series, particlarly when filling layered vesicles. In such cases, there is an increase in sodium from the rim, $E_{1}$, inward through an inner ring of $E_{2}$, and finally to a core composed of the sodium-rich mineral $\mathrm{E}_{3}$.

Pseudomorphs are the source of most analyses of this type. They generally occur with other secondary phases as rims or internal veins, but may very rarely form the high-sodium, high-calcium blebs mentioned in an earlier section.

\section{Chlorite Mixed-Layer Minerals}

The presence of chlorite-smectite mixed-layer minerals is based primarily on geochemical evidence, with some additional support from diffractogram sources.

An ideal chlorite analysis calculated on the basis of 22 oxygens has a zero exchangeable cation capacity, and a SAMF value of 15.7. Dilution of chlorite by varying amounts of 2:1 layered clays increases the inter-layer charge from zero to values proportional to the percentage of clay in the mixture. SAMF decreases from 15.7 in a similar manner. The principal criteria used in recog- 
Table 2. Average chemical compositions for all clusters.

\begin{tabular}{|c|c|c|c|c|c|c|c|c|c|c|c|c|c|c|c|c|c|c|c|c|c|c|c|c|c|c|c|}
\hline Type $^{\text {a }}$ & $E_{0}$ & $E_{1}$ & $E_{2}$ & $E_{3}$ & $E_{4}$ & $E_{5}$ & $\mathrm{~T}_{0}$ & $T_{1}$ & $\mathrm{~T}_{2}$ & $\mathrm{~s}_{0}$ & $s_{1}$ & $s_{2}$ & $S_{3}$ & $\mathrm{~S}_{4}$ & $A_{1}$ & $A_{2}$ & $A_{3}$ & $\mathrm{~A}_{4}$ & $A_{5}$ & $\mathrm{~A}_{6}$ & $\mathbf{R}_{2}$ & $\mathbf{R}_{3}$ & $\mathrm{R}_{4}$ & $R_{5}$ & $Q_{3}$ & $\mathrm{Q}_{4}$ & Qs \\
\hline $\mathrm{SiO}_{2}$ & 46.20 & 52.80 & 54.00 & 52.10 & 43.10 & 38.20 & 44.80 & $\begin{array}{r}53.80 \\
0.02\end{array}$ & $\begin{array}{r}52.60 \\
0.05\end{array}$ & $\begin{array}{r}44.10 \\
0.01\end{array}$ & $\begin{array}{r}47.00 \\
0.07\end{array}$ & $\begin{array}{r}47.70 \\
0.09\end{array}$ & $\begin{array}{r}50.70 \\
0.12\end{array}$ & 52.30 & $\begin{array}{r}46.10 \\
0.23\end{array}$ & $\begin{array}{r}49.30 \\
0.32\end{array}$ & $\begin{array}{r}44.00 \\
0.91\end{array}$ & $\begin{array}{r}52.00 \\
0.39\end{array}$ & $\begin{array}{r}54.10 \\
0.40\end{array}$ & 58.20 & 45.30 & $\begin{array}{r}49.60 \\
0.27\end{array}$ & $\begin{array}{r}48.90 \\
0.38\end{array}$ & $\begin{array}{r}53.90 \\
0.67\end{array}$ & $\begin{array}{r}43.10 \\
0.16\end{array}$ & $\begin{array}{r}36.50 \\
0.74\end{array}$ & $\begin{array}{r}46.70 \\
0.77\end{array}$ \\
\hline $\begin{array}{l}11 \mathrm{O}_{2} \\
\mathrm{Al}_{2} \mathrm{O}\end{array}$ & 0.12 & 1.59 & 1.08 & 0.74 & 1.47 & 3.82 & 1.18 & $\begin{array}{l}0.02 \\
1.52\end{array}$ & 0.34 & $\begin{array}{l}0.01 \\
5.88\end{array}$ & 5.36 & $\begin{array}{l}0.09 \\
5.87\end{array}$ & $\begin{array}{l}0.12 \\
5.10\end{array}$ & 3.03 & $\begin{array}{r}0.23 \\
10.14\end{array}$ & $\begin{array}{l}0.32 \\
9.98\end{array}$ & $\begin{array}{l}0.91 \\
15.02\end{array}$ & $\begin{array}{r}0.39 \\
23.28\end{array}$ & $\begin{array}{l}0.40 \\
23.14\end{array}$ & 23.73 & 8.62 & 9.26 & $\begin{array}{l}0.38 \\
12.33\end{array}$ & $\begin{array}{l}0.07 \\
11.74\end{array}$ & $\begin{array}{l}8.10 \\
8.23\end{array}$ & $\begin{array}{l}0.74 \\
7.78\end{array}$ & 10.37 \\
\hline & 22.60 & 11.70 & 7.38 & & & & 23.30 & 10.85 & 5.36 & 13.82 & 11.54 & 13.78 & 17.73 & 24.43 & $\begin{array}{l}11.614 \\
11.61\end{array}$ & 11.62 & 14.40 & 6.40 & 6.20 & 1.60 & 10.40 & 11.82 & 10.47 & 10.80 & $\begin{array}{l}9.50 \\
9.50\end{array}$ & 23.30 & 12.50 \\
\hline $\mathrm{N}$ & & & 0.02 & & & & 0.03 & & 0.07 & 0.02 & & 0.02 & 0.04 & & 0.10 & 0.66 & 0.24 & 0.06 & 0.09 & & & 0.07 & 0.08 & 0.04 & & 0.08 & 0.15 \\
\hline $\mathrm{M}$ & 15.03 & 22.73 & 25.34 & 24.40 & 5.01 & 10.32 & 15.20 & 22.08 & 22.10 & 19.87 & 20.07 & 16.74 & 12.20 & 5.53 & 18 & $\begin{array}{l}17.57 \\
\end{array}$ & 11.44 & 5.27 & 4.78 & 0.19 & 19.33 & 17.31 & 11.60 & 10.03 & 17.35 & & 10.61 \\
\hline & 0.33 & 0.61 & 0.24 & 0.27 & 0.28 & 2.34 & 0.53 & 0.73 & 0.31 & 0.94 & 1.19 & 2.25 & 1. & & 1. & 1.84 & 1.20 & & 1.44 & 1.60 & 5.70 & & & & & 11.36 & 13.68 \\
\hline $\mathrm{N}$ & 0.61 & $\begin{array}{l}2.01 \\
2.03\end{array}$ & 5.14 & $\begin{array}{c}0.27 \\
10.67\end{array}$ & 9.11 & $\begin{array}{r}2.34 \\
14.12\end{array}$ & 0.52 & 0. & 0.40 & 1.1 & 1.1 & 1.2 & 0.95 & 33 & 0.79 & 1.2 & 1.4 & & i. & 3.88 & 0.52 . & 2. & 0 & 3.2 & & 0.30 & $\begin{array}{r}0.76 \\
0.76\end{array}$ \\
\hline $\mathrm{K}_{2} \mathrm{O}$ & 1.61 & 0.35 & 0.29 & 0.30 & 3.84 & 0.31 & 1.04 & 0.16 & 0.34 & 0.19 & 0.25 & 0.41 & 2.53 & 5.91 & 0.59 & 0.25 & 1.49 & 1.26 & 1.42 & 0.13 & 0.33 & 0.43 & 0.38 & 0.30 & 0.20 & 0.36 & \\
\hline Total & 86.50 & 91.81 & 93.49 & 95.94 & 90.91 & 85.41 & 86.60 & 89.45 & 81.57 & 85.96 & 86.64 & 88.07 & 91.09 & 92.45 & 89.84 & 92.80 & 90.18 & 91.02 & 92.63 & 89.33 & 90.20 & 94.50 & 91.49 & 96.40 & 86.69 & 88.59 & 95.54 \\
\hline $\mathrm{Si}$ & 7.48 & 7.50 & 7.46 & 7.21 & 7.22 & 6.54 & 7.27 & 7.71 & 8.01 & 6.83 & 7.10 & 7.17 & 7.53 & 8.00 & 6.72 & 6.93 & 6.50 & 7.05 & 7.08 & 7.73 & 6.64 & 6.91 & 6.98 & 7.27 & 6.60 & 6.07 & 6.64 \\
\hline Al & $\begin{array}{l}1.48 \\
0.02\end{array}$ & 0.27 & $\begin{array}{l}1.40 \\
0.17\end{array}$ & 0.12 & & $\begin{array}{l}0.34 \\
0.77\end{array}$ & 0.23 & 0.3 & 8.01 & & & & 0.47 & 8.00 & 1.28 & & & & & & & & & & & $\begin{array}{l}1.01 \\
1.52\end{array}$ & \\
\hline $\mathrm{Al}$ & & & & & & & & & 0.06 & & 0.05 & 0.2 & 0.42 & 0.55 & 0.4 & & 1.2 & & 2. & 3.45 & 0.13 & & & & & & \\
\hline $\begin{array}{l}\mathrm{Al} \\
\mathrm{Ti}\end{array}$ & & & & & & & & 0.01 & $\begin{array}{l}0.06 \\
0.01\end{array}$ & & & & 0. & & 0. & & 0.10 & & 0. & & 0.19 & & & $\begin{array}{l}1.21 \\
0.07\end{array}$ & & 0.10 & \\
\hline $\mathrm{Fe}^{2+}$ & 3.06 & 1.39 & & 0.86 & 3.94 & 2.33 & & $\begin{array}{l}.01 \\
1.30\end{array}$ & 0.68 & & 1.46 & 1.73 & 2.20 & 3.13 & 1.41 & 1.3 & 1.78 & & 0.5 & 0.18 & 1.27 & $\begin{array}{l}1.38 \\
\text { S }\end{array}$ & & 1.22 & 1.22 & & \\
\hline $\begin{array}{l}\mathrm{Fe}^{-2} \\
\mathrm{Mn}\end{array}$ & 3.06 & 1.39 & $\begin{array}{l}0.85 \\
0.01\end{array}$ & 0.86 & 3.94 & 2.33 & $\begin{array}{l}3.16 \\
0.01\end{array}$ & & $\begin{array}{l}0.68 \\
0.01\end{array}$ & $\begin{array}{l}1.79 \\
0.01\end{array}$ & 1.46 & & $\begin{array}{l}2.20 \\
0.01\end{array}$ & 3.13 & $\begin{array}{l}1.41 \\
0.01\end{array}$ & & $\begin{array}{l}1.18 \\
0.03\end{array}$ & & 0.0 & 0.18 & 1.27 & & & $\begin{array}{l}1.22 \\
0.01\end{array}$ & 1.22 & & \\
\hline $\mathrm{Mg}$ & 3.63 & 4.81 & 5.22 & 5.03 & 1.25 & 2.63 & $\begin{array}{l}3.01 \\
3.68\end{array}$ & 4.72 & 5.0 & 4.59 & 4.52 & & 2.70 & 1.26 & & & & & & 0.04 & 4.22 & & & & 96 & & 2.25 \\
\hline $\mathrm{Ca}$ & & 0.09 & 0.0 & 0.0 & & & 0.09 & 0.11 & 0.0 & 0.1 & & & 0.27 & & 0.27 & & & & & & & & & & & & 2.08 \\
\hline $\begin{array}{l}\mathrm{Na} \\
\mathrm{Na}\end{array}$ & 0.1 & $\begin{array}{l}0.09 \\
0.56\end{array}$ & 1.3 & 2.86 & 2 . & 4. & 0. & 0 . & 0.1 & 0. & 0. & & $\begin{array}{l}0.27 \\
0.27\end{array}$ & 0.10 & $\begin{array}{l}0.27 \\
0.22\end{array}$ & 0.34 & & & & & & & & & & $\begin{array}{l}2.102 \\
0.10\end{array}$ & 0.21 \\
\hline K & 0.33 & 0.06 & 0.05 & 0.05 & 0.82 & 0.07 & 0.21 & 0.03 & 0.07 & 0.04 & 0.05 & 0.08 & 0.48 & 1.15 & 0.11 & 0.05 & 0.28 & 0.22 & 0.24 & 0.02 & 0.06 & 0.08 & 0.07 & 0.05 & 0.04 & 0.07 & \\
\hline & 4 & & 9 & & 1 & & 5 & & & & & & & 4 & 12 & 7 & & 2 & 4 & 3 & 2 & 9 & 5 & 3 & 6 & 5 & \\
\hline & 14.20 & 14.00 & 13.70 & 13.22 & 12.70 & 12.27 & 14.33 & $\begin{array}{l}13.99 \\
13.99\end{array}$ & 13.77 & 14.28 & $\begin{array}{l}14.03 \\
14.03\end{array}$ & 13.69 & $\begin{array}{l}11.32 \\
13.32\end{array}$ & 12.94 & 13.90 & 13.63 & 13.42 & 12.54 & 12.10 & 11.66 & 13.62 & 13.40 & 12.78 & 12.38 & & 12.85 & 12.12 \\
\hline$e^{3+}$ & $\begin{array}{r}14.20 \\
0.02\end{array}$ & $\begin{array}{r}14.0 \\
0.2\end{array}$ & 0.1 & $\begin{array}{r}13.2 \\
0.1\end{array}$ & $\begin{array}{c}12 . \\
0 .\end{array}$ & 0.7 & $\begin{array}{c}14.3 \\
0.2\end{array}$ & 0.3 & 0. & 1.0 & $\begin{array}{r}14.95 \\
0.95\end{array}$ & 1.0 & $\begin{array}{r}0.89 \\
0.82\end{array}$ & 0.55 & $\begin{array}{l}13.90 \\
1.74\end{array}$ & 1.6 & $\begin{array}{r}2.42 \\
2.62\end{array}$ & 3. & 3.5 & 3. & $\begin{array}{l}1.49 \\
\end{array}$ & 1.52 & 2. & $\begin{array}{l}1.87 \\
\end{array}$ & 1. & 1.52 & 1.74 \\
\hline & 0.64 & $\begin{array}{l}0.27 \\
0.80\end{array}$ & 1.4 & 2.9 & 3. & 5.6 & 0.5 & 0.33 & $\begin{array}{l}0.28 \\
0.28\end{array}$ & 0.69 & 0. & 1.1 & $\begin{array}{l}1.0 \\
1.2\end{array}$ & 1.55 & 0. & 0. & 1.0 & 0.8 & 0.9 & 1.4 & 1.99 & 1.72 & 2. & 2.54 & $\begin{array}{l}2.67 \\
2.67\end{array}$ & $\begin{array}{l}1.21 \\
4.21\end{array}$ & $\begin{array}{l}4.37 \\
\end{array}$ \\
\hline$(\mathrm{Mg}+\mathrm{F}$ & $\begin{array}{l}0.04 \\
6.69\end{array}$ & $\begin{array}{l}.080 \\
6.20\end{array}$ & $\begin{array}{l}1.49 \\
6.10\end{array}$ & $\begin{array}{l}2.99 \\
5.89\end{array}$ & $\begin{array}{l}3.18 \\
5.20\end{array}$ & $\begin{array}{l}3.01 \\
4.96\end{array}$ & $\begin{array}{l}0.35 \\
6.84\end{array}$ & $\begin{array}{l}0.35 \\
6.0\end{array}$ & $\begin{array}{l}0.28 \\
5.7\end{array}$ & $\begin{array}{l}6.09 \\
6.4\end{array}$ & 5.98 & $\begin{array}{l}1.10 \\
5.48\end{array}$ & $\begin{array}{l}1.29 \\
4.90\end{array}$ & 4.4 & 5.44 & $\begin{array}{l}5.05 \\
5.05\end{array}$ & $\begin{array}{l}1.00 \\
4.30\end{array}$ & $\begin{array}{l}.68 \\
1.79\end{array}$ & $\begin{array}{l}.91 \\
1.47\end{array}$ & 0.21 & 5.49 & 4.97 & 3.72 & 3.24 & 5.18 & 5.26 & $\begin{array}{l}4.37 \\
3.74\end{array}$ \\
\hline
\end{tabular}

${ }^{a}$ See footnote under Table 1. 


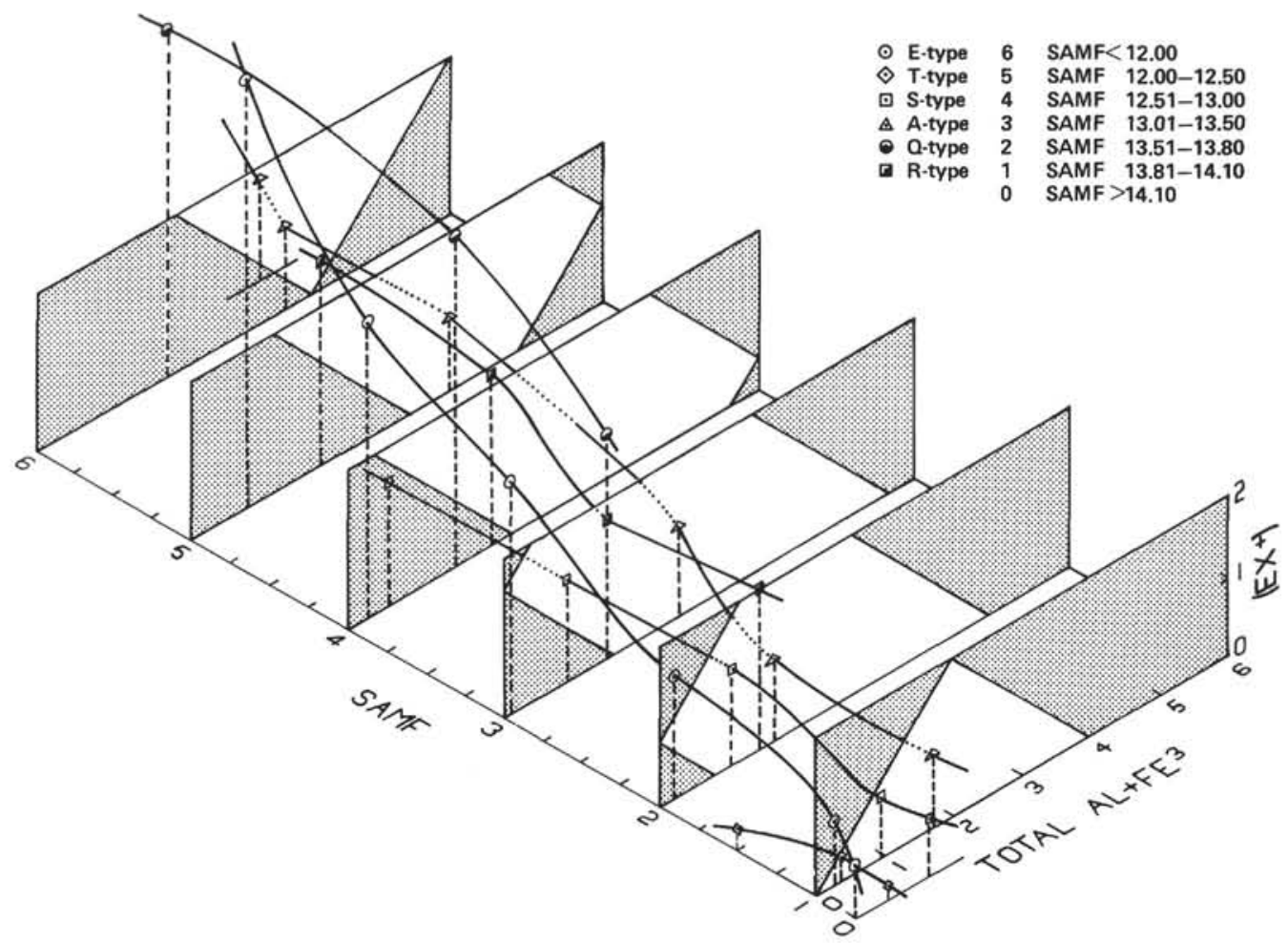

Figure 5. Average values calculated for each cluster of analyses in Figure 4 and plotted on a three-dimensional isometric projection. Fields for each division of SAMF are shown, as in Figure 2. Points belonging to a single mineral type are joined by continuous lines to show the overall spatial relationships between the different mineral types. Note particularly how most of the E-, Q-, and R-type minerals fail to satisfy the field requirements for the 2:1 layered clays.

nizing chlorite analyses are high SAMF values with low inter-layer charge.

The most convincing mixed chlorite analysis available at present comes from the center of a layered vein composed of A-type minerals, in the altered glass margins of a pillow (Sample 504B-7-2, Piece 466). The chemistry can be explained by mixing in equal amounts saponite with an approximate formula $\left(\mathrm{EX}^{+}\right)_{0.4}\left(\mathrm{Mg}, \mathrm{Fe}^{2+}\right)_{6}$ $\mathrm{Si}_{7.6} \mathrm{Al}_{0.4} \mathrm{O}_{20}(\mathrm{OH})_{4}$ and a chlorite such as pynochlorite (Deer et al., 1962) $\mathrm{Al}_{2.5}\left(\mathrm{Mg}, \mathrm{Fe}^{2+}\right)_{9.5} \mathrm{Si}_{5.7} \mathrm{Al}_{2.7} \mathrm{O}_{20}(\mathrm{OH})_{16}$

It is of interest to note that the chlorite, characteristic of higher temperatures of alteration, is found close to the basalt/sediment interface, where temperatures are relatively low. Precipitation of this phase formed the final episode of alteration in the pillow basalts at this horizon.

\section{Zeolites}

At the time of this writing, little work has been conducted on zeolites. Thomsonite and analcite have been positively identified from Hole 504B by XRD methods. These, in common with other zeolite occurrences, from visual and microscopic observations of the core, occur either alone or with clays in varying proportions as fillings to veins and pseudomorphs. Zeolites also appear in many pillow margins, forming relatively late in the alteration sequence. The growth of fracture-filling zeolites usually follows an earlier phase of clay precipitation, giving a layered appearance, characteristic radiat- ing crystal sprays completely filling veins where permeability fell sufficiently to inhibit smectite formation (Velde, 1977). In other cases, the contemporaneous development of zeolites and other minerals diminishes layered appearances and results in a mottled effect.

\section{Carbonates}

Both aragonite and calcite have been positively identified in several samples from Hole 504B using XRD. Of these samples, the deepest is approximately 150 meters into basement, though carbonates are usually evident to much greater depths than this.

Carbonates appear late in the alteration sequence, forming the centers of veins, green smectites generally acting as an envelope against the rock walls. Contacts are sharp, lacking any gradational zone. Aragonite crystals often cut or truncate smectite fibers growing perpendicular to vein walls. In other cases, crystallization of aragonite follows existing smectite layers, filling the remaining cavities. Occasionally, a vague discontinuity is evident down the center of calcite veins filled by amorphous clay material, probably the result of renewed fracturing and late smectite precipitation.

Following the reasoning of Pritchard (1979), rapid alteration of basalt glass at a late stage seems to provide not only calcium ions, but also hydroxyl ions. These hydroxyl ions displace the normal bicarbonate-carbonate equilibrium in such a way that large quantities of calcite can form. This process is probably assisted by the re- 


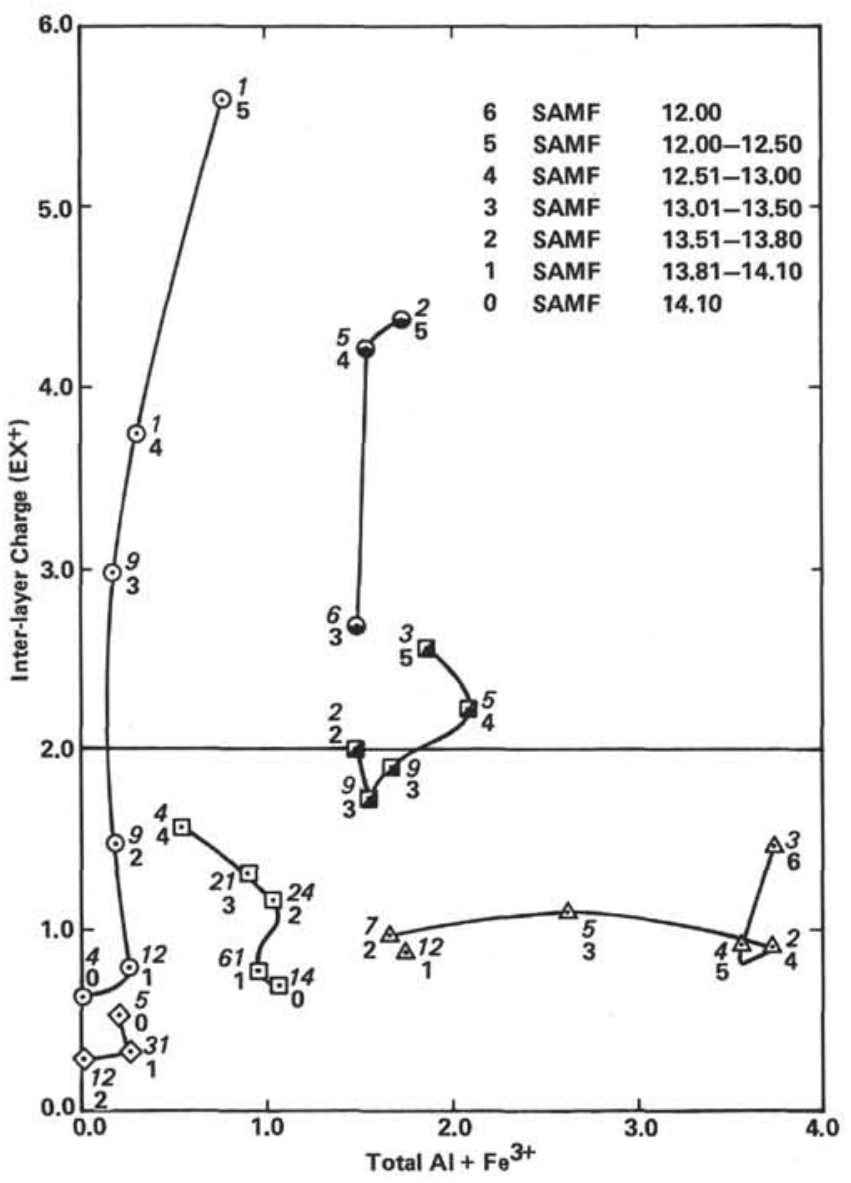

Figure 6. The isometric projection of Figure 5 projected onto a single plane, the SAMF divisions to which each point belongs, and the number of contributing analyses in the original cluster (Fig. 4). (Symbols same as in Fig. 5; numbers in italic denote number of analyses for that point.) moval of $\mathrm{Mg}$ ions from solution, into clays, which normally inhibit calcite nucleation.

\section{DISCUSSION}

The alteration processes replacing primary minerals in situ and those precipitating clays in veins and vesicles differ substantially. This section will first discuss the processes which control the precipitation of clay within vesicles, and then those which control the filling of fractures. Finally, the processes affecting in situ alteration will be briefly discussed.

Individual mineral trends within vesicles recognized by using three-dimensional graphics probably delineate some form of continuous reaction series. Possibly ionic diffusion, or changes in circulating-fluid chemistry can affect certain tri- and dioctahedral minerals in such a way as to systematically change their chemistry to follow a specific mineral trend. This continuous reaction series is especially evident in the case of the saponites and the E-type minerals. In both cases, optically layered vesicles occur which contain several members of a particular series in sequence, each with diffuse contacts. To account for these observations, two possible processes of formation may be operating - first is a process of "constructive" alteration; here, very slow but continuous precipitation of a mineral phase occurs, gradually changing chemically to reflect the fluctuations in circulating fluid chemistry with time.

Second is a process of "destructive" alteration where leaching processes are dominant. Pre-existing minerals are chemically changed to follow one of the chemical trends by removal of mobile elements into circulating pore fluids. In the case of layered vesicles containing minerals from different series with sharp contacts, it seems likely that a different process of formation may be operative. In contrast to the envisaged continuous

Table 3. Effect of oxidation state of iron on graphical parameter.

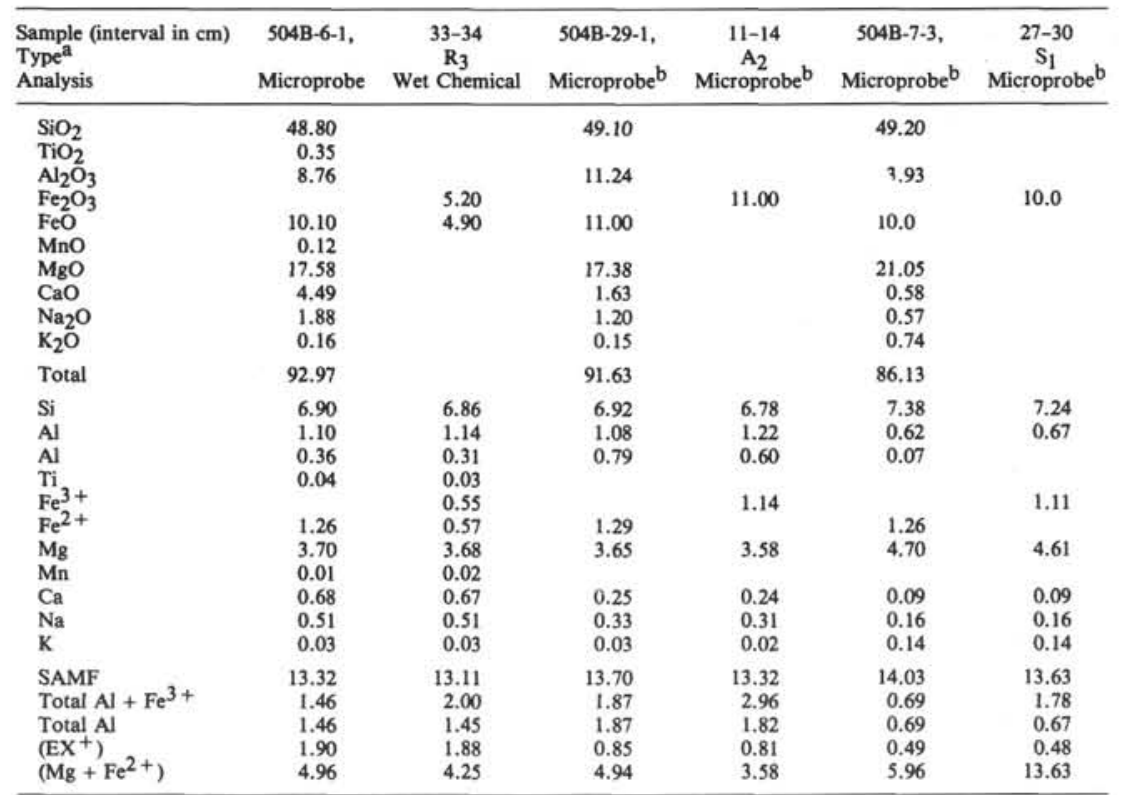

See footnote under Table 1 .

botal iron is assumed to be $\mathrm{Fe}^{2+}$ or $\mathrm{Fe}^{3+}$. 
processes of formation which produce diffuse layering, sharp contacts suggest that cavities are filled by a multistage process. Initially a rim is precipitated, followed by formation of a core of a different mineral type.

Irrespective of the type of process precipitating layered clays, their study can act as an indicator of temporal change in fluid chemistry in the area of vesicles.

Clay precipitation in veins appears to be subject to considerable variation. Clays of many different morphologies often occur in close proximity, and layering, when evident, can be sharp or diffuse. Late-phase carbonates and zeolites are common in several localities. Initial investigation of layered veins has shown remarkably little chemical variation between individual layers and clays of different morphology. Apparently, the presence of visible layering bears little relationship to majorelement chemistry. This will be further investigated. Most veins away from pillow margins contain minerals belonging to a single clay type. Where veins are more heterogeneous, precipitation is probably governed by the same considerations discussed earlier for the case of vesicles. Possibly the lack of clay variety in most analyzed veins is a result of precipitation from pore fluids which are chemically highly constant. Diffusive alterations of pre-existing secondary phases, termed destructive alteration above, are probably of little importance in the filling of veins.

The process of in situ alteration of primary minerals and basaltic glass differs fundamentally from that governing the precipitations of clay from solution. Here, primary mineralogy, not pore-fluid chemistry, exerts a very strong, if not dominant effect on the occurrence and distribution of the secondary minerals. In the case of basaltic glass, mineral phases develop which are rich in the less-mobile elements such as $\mathrm{Al}$ and $\mathrm{Ti}$, forming the montmorillonite-like clays, $\mathbf{A}_{4}-\mathrm{A}_{6}$. Such phases are rarely found as the products of precipitation. Alteration of olivine generally forms $\mathrm{Mg}$-rich phases, principally talclike minerals and saponite. The alteration of olivine begins at the rim and along cracks penetrating the crystal, and later proceeds to the rest of the crystal. For plagioclases, the calcic core is the first part of a crystal to be replaced, whereas the sodic rims consistently remain intact.

No consistent differences in the chemistry of the alteration minerals can be found between the cold, open crust at Site 505 and the hot, sealed crust at Sites 501 and 504. The various secondary mineral types described here are present in the rocks from each hole. There is, however, a marked difference in the degree of replacement that has occurred. The hot, sealed crust is much more intensely altered than the cold, open site, where fresh olivine can still be found. This difference can be assigned to the difference in temperature and the consequently different rates of alteration in the two areas. However, the difference in temperature does not appear to have been sufficient to affect the chemistry and mineral type of the minerals being formed.

In many of the thin-sections probed in this study, particularly those from Site 504, there are a great number of different clay types in close proximity. These may be in homogeneous or heterogeneous vesicles, veins, or pseudomorphs. Such a variety on a small scale suggests that the circulation of pore fluids within the rock is very restricted in scope. Rapid flow, producing a high water/ rock ratio, would lead to the imposition of a homogeneous alteration mineralogy on the whole rock, because the controlling chemistry would be that of the circulating solution, not that of the local solids. Here it seems that water/rock ratios generally must have been small, so that the rock has dominated the alteration pattern, even in the hot, sealed crust at Sites 501 and 504.

At Site 504, the general pattern of a high variety of the clays developed persists with depth in the crust. Clearly, the higher temperatures at the bottom of the hole were not able to promote the circulation of water to a degree sufficient to affect the essentially rock-dominated chemistry. If free circulation is confined within the section to fault zones or other regions of intense cracking, sections of the core should be identifiable in which a water-dominated homogeneous clay association develops. This study has not identified such an area, but the samples were taken at individual spots down the core not necessarily associated with fracturing. It is possible that further study will identify water-dominated regions in the core, and this work is in progress.

\section{ACKNOWLEDGMENTS}

Grateful thanks go to Pete Treloar of Cambridge for help in running the electron-probe, to Peter Oakley for advising with wet chemical analysis, to Dave Robson for his assistance in the computer handling of data, and to Joe Cann for the original idea of presenting clay analyses using three-dimensional graphics, and for many stimulating discussions. I would also like to thank Dr. M. H. Battey and Dr. Gary Pritchard for reviewing this paper. The author was supported by a N.E.R.C. grant throughout the work.

\section{REFERENCES}

Andrews, A. J., 1977. Low temperature fluid alteration of oceanic layer 2 basalts, DSDP Leg 37. Can. J. Earth Sci., 14:911-926.

Bailey, S. W., 1980. Structures of layered silicates. In Brindley, G. W., and Brown, G. (Eds.), Crystal Structures of Clay Minerals and Their X-Ray Identification: Mineralogical Society, Monograph No. 5, London, pp. 1-124

Baragar, W. R. A., Plant, A. G., Pringle, G. J., and Schaw, M., 1977. Petrology and alteration of selected units of Mid-Atlantic Ridge basalts sampled from Sites 332 and 335, DSDP. Can. J. Earth Sci., 14:837-874.

Bass, M. N., 1976. Secondary minerals in oceanic basalts, with special reference to Leg 34, Deep Sea Drilling Project. In Yeats, R. S., Hart, S. R., et al., Init. Repts. DSDP, 34: Washington (U.S. Govt. Printing Office), 393-432.

Bohlke, J. K., Honnorez, J., and Honorez-Guerstein, B.-M., 1980. Alteration of basalts from Site 396B, DSDP: petrographic and mineralogic studies. Contr. Mineral. Petrol., 73:341-364.

Cann, J. R., 1979. Metamorphism in the oceanic crust, 1979. In Talwani, M., Harrison, C. G., and Hayes, D. E., (Eds.), Deep Drilling Results in the Atlantic Ocean: Ocean Crust: Washington (Am. Geophys. Union), pp. 230-238.

Deer, W. A., Howie, R. A., and Zussman, J., 1962. Rock Forming Minerals (Vol. 3): London (Longmans).

Donnelly, T. W., 1978. Low temperature alteration on the oceanic crust [paper presented at the Ewing Symposium, New York, March, 1978].

Donnelly, T. W., Pritchard, R. G., Emmerman, R., and Puchelt, H., 1979. The aging of oceanic crust: synthesis of the mineralogical and chemical results of Deep Sea Drilling Project, Legs 51 through 53. In Donnelly, T. W., Francheteau, J., Bryan, W. B., Robinson, P. T., Flower, M. F. I., Salisbury, M., et al., Init. Repts. $D S D P, 51,52,53$, Pt. 2: Washington (U.S. Govt. Printing Office), 1563-1577. 
Donnelly, T. W., Thompson, G., and Salisbury, M. H., 1979. The chemistry of altered basalts at Site 417, Deep Sea Drilling Project. In Donnelly, T. W., Francheteau, J., Bryan, W. B., Robinson, P. T., Flower, M. F. I., Salisbury, M., et al., Init. Repts. DSDP, 51, 52, 53, Pt. 2: Washington (U.S. Govt. Printing Office), 1319-1330.

Hart, R. A., 1973. A model for chemical exchange in the basalt-seawater system of oceanic layer 2. Can. J. Earth Sci., 10:799-816.

Pertsev, N. N., and Rusinov, V. L., 1979. Mineral assemblages and processes of alteration in basalts at Deep Sea Drilling Project Sites 417 and 418. In Donnelly, T. W., Francheteau, J., Bryan, W. B., Robinson, P. T., Flower, M. F. I., Salisbury, M., et al., Init. Repts. DSDP, 51, 52, 53, Pt. 2: Washington (U.S. Govt. Printing Office), 1219-1242.

Peterson, N., 1978. Low temperature alteration of the magnetic minerals in ocean floor basalts [a paper presented at the Ewing Symposium, New York, March, 1978].

Pritchard, R. G., 1979. Alteration of basalts from Deep Sea Drilling Project Legs 51, 52 and 53, Holes 417A and 418A. In Donnelly, T. W., Francheteau, J., Bryan, W. B., Robinson, P. T., Flower, M.
F. I., Salisbury, M., et al., Init. Repts. DSDP, 51, 52, 53, Pt. 2: Washington (U.S. Govt. Printing Office), 1185-1199.

Pritchard, R. G., Cann, J. R., and Wood, D. A., 1978. Low-temperature alteration of oceanic basalts, DSDP Leg 49. In Cann, J. R. Luyendyk, B. P., et al., Init. Repts. DSDP, 49: Washington (U.S. Govt. Printing Office), 709-714.

Rusinov, V. L., Laputina, I. P., Muravitskaja, G. N., Zujagin, B. B., and Gradusov, B. P., 1979. Clay minerals in basalts from Deep Sea Drilling Project Sites 417 and 418. In Donnelly, T. W., Francheteau, J., Bryan, W. B., Robinson, P. T., Flower, M. F. I., Salisbury, M., et al., Init. Repts. DSDP, 51, 52, 53, Pt. 2: Washington (U.S. Govt. Printing Office), 1265-1271.

Scarfe, C. M., and Smith, D. G. W., 1977. Secondary minerals in some basaltic rocks from DSDP, Leg 37. Can. J. Earth Sci., 14:903-910.

Scott, R. B., and Hajash, A., 1976. Initial submarine alteration of basaltic pillow lavas: a microprobe study. Am. J. Sci., 276:480-501.

Velde, B., 1977. Clays and clay minerals in natural and synthetic systems. Developments in Sedimentology, 21: Amsterdam (Elsevier). 